\title{
A Long Walk Home: The Role of Class and the Military in the Springsteen Catalogue
}

\author{
Michael S. Neiberg \\ United States Army War College \\ and \\ Robert M. Citino \\ National World War II Museum ${ }^{1}$
}

\begin{abstract}
This article analyzes the themes of class and military service in the Springsteen canon. As a member of the baby boom generation who narrowly missed service in Vietnam, Springsteen's reflection on these heretofore unappreciated themes should not be surprising. Springsteen's emergence as a musician and American icon coincide with the end of conscription and the introduction of the All-Volunteer Force in 1973. He became an international superstar as Americans were debating the meaning of the post-Vietnam era and the patriotic resurgence of the Reagan era. Because of this context, Springsteen himself became involved in veterans issues and was a voice of protest against the 2003 Iraq War.
\end{abstract}

In a well-known monologue from his Live 1975-85 box set (1986), Bruce Springsteen recalls arguing with his father Douglas about the younger Springsteen's plans for his future. Whenever Bruce provided inadequate explanations for his life goals, Douglas responded that he could not wait for the Army to "make a man" out of his long-haired, seemingly aimless son. Springsteen

\footnotetext{
${ }^{1}$ Copyright $($ ) Michael S. Neiberg and Robert M. Citino, 2016. Michael Neiberg would like to thank Derek Varble, with whom he saw Springsteen in concert in Denver in 2005, for his helpful comments on a draft of this article. Address correspondence to neiberg102@gmail.com or rcitino@gmail.com.
}

BOSS: The Biannual Online-Journal of Springsteen Studies 2.1 (2016) $\underline{\text { http://boss.mcgill.ca/ }}$ 
describes his fear as he departed for an Army induction physical in 1968, at the height of domestic discord over the Vietnam War. He returned home terrified of the reaction to what he assumed his father would receive as bad news: Bruce had failed his physical. The Army had rejected him. Douglas replied simply, "That's good."

Listeners might have expected Springsteen to follow this monologue with an anti-war song such as "Born in the U.S.A." or his cover of Edwin Starr's "War," which receives its own powerful introduction on the album. The story of his rejection by the Army also could have served as an opening for one of Springsteen's songs about fathers and sons such as "My Father's House," "Independence Day," or "Adam Raised A Cain." Instead, Springsteen follows with the plaintive wail on the harmonica that introduces "The River," and the audience bursts into applause. That song describes the tribulations of working-class life in a struggling industrial northeastern city. The narrator lives his life not as he chooses but as the events and social expectations around him dictate. The free-falling economy has robbed him of access to the well-paying working-class jobs his father's generation had once enjoyed almost as a birthright, and his girlfriend's pregnancy denies him a consequence-free youth and a happy wedding day. Instead, the narrator lives a life of intermittent employment as empty as the dry riverbed that calls him down in the hopes of recovering some of the joy of his young life. "Is a dream a lie if it don't come true," the narrator asks in the song's emotional climax, "or is it something worse?"

"The River" and its introduction on Live highlight the connection between class and military service that sits at the center 
of Springsteen's canon. Taken together, "The River" and Springsteen's monologue illustrate the limited choices available to young working-class men in a rapidly deindustrializing America at the end of the twentieth century. Many working-class men in the 1960s and early 1970s faced two options: risk life and limb in the military or suffer the vagaries of financial insecurity in a declining domestic economy. As historians and economists have observed, and as Springsteen later bemoaned in "Youngstown," deindustrialization marked the end of high-paying, seemingly secure factory jobs in the United States, and the closure of factories rapidly removed the most common life path for young men without college educations. ${ }^{2}$ At age 19, the narrator of "The River" receives "a union card and a wedding coat," symbolic of the two institutions likely to confine his life choices even further. Though "The River" is based on circumstances in the lives of Springsteen's sister and brother-in-law, Springsteen was also 19 when he failed his Army physical. Though he had successfully avoided military service, the pairing of this song and the monologue implies that had Springsteen not made it as a musician an equally restrictive and dangerous fate might have awaited him.

This article considers the overlooked intersection of class and the military in Springsteen's canon and biography since the 1970s. In particular, we analyze the military figures who populate Springsteen's lyrics. We argue that Springsteen's soldiers bear

\footnotetext{
2 Barry Bluestone and Bennett Harrison, The Deindustrialization of America: Plant Closings, Community Abandonment, and the Dismantling of Basic Industry (New York: Basic Books, 1982); on the deindustrialization of Youngstown, Ohio, and Springsteen's musical response, see Sherry Lee Linkton and John Russo, Steeltown U.S.A: Work and Memory in Youngstown (Lawrence, KS: University Press of Kansas, 2002).
}

BOSS: The Biannual Online-Journal of Springsteen Studies 2.1 (2016) 
unmistakable marks of the essentially working-class military experience of the Vietnam era. Analysis of Springsteen's responses to the Vietnam War and the military figures who appear in his songs highlights a previously overlooked element of Springsteen's class politics. ${ }^{3}$ Though often silent on the propriety of American wars, Springsteen has demonstrated a deep concern for American soldiers and has frequently highlighted their mistreatment as evidence of an unfulfilled American promise, one borne disproportionately by the working-class. In their essay, Jefferson Cowie and Lauren Boehm read "Born in the U.S.A." as the particular expression of a post-Vietnam white working-class whose military experience remains inextricable from class identity. ${ }^{4}$ This notion extends further to Springsteen's other songs that deal with military characters. The American working class faced a particular experience of Vietnam that Springsteen narrowly avoided and which his friends were exposed to. This classed vision of war and military service has proven a staple of Springsteen's canon for decades, including his reflections on the Gulf War, the Iraq War, and the fate of American veterans in the twenty-first century.

By 1982, the year he wrote "Born in the U.S.A.," Springsteen had come to a critical understanding about the military in general and the Vietnam War in particular. Unlike the men in many of Springsteen's early songs who flee entrapping towns and lifestyles, working-class men of the Vietnam generation, like Springsteen

\footnotetext{
${ }^{3}$ On Springsteen's notion of politics, see Roxanne Harde, "'Living in Your American Skin': Bruce Springsteen and the Possibility of Politics," Canadian Review of American Studies, Vol. 43 No. 1 (Spring 2013): 125-144.

4 Jefferson Cowie and Lauren Boehm, "Dead Man's Town: 'Born in the U.S.A.,' Social History, and Working-Class Identity," American Quarterly, Vol. 58 No. 2 (June 2006): 353-378.
}

BOSS: The Biannual Online-Journal of Springsteen Studies 2.1 (2016) 
himself, had little control over their fates. Military service had always come with a certain level of caprice, but, in the Vietnam era, policy decisions linked that caprice directly to social class. Because America had far more men than it could conscript with any semblance of equality, and because Vietnam was a limited war in scope and aims, "chance and circumstance," in the words of Lawrence Baskir and William Strauss, played an outsized role in a draft process badly biased against working-class men. ${ }^{5}$ For example, Springsteen's failed induction physical kept him out of Vietnam. While a concussion and leg injury sustained in a motorcycle accident may have contributed to his rejection, Springsteen believes the Army decline to enlist him because, in a wild act of teenage rebellion and desperation, he checked all of the boxes on the induction form, including the one asking if he were gay. ${ }^{6}$ By so doing, he used one of the few available tools to manipulate a system rigged against him. Of course, there is no way to know for certain if Springsteen's behavior at his physical was the definitive cause of his rejection, or if some unforeseen factor in the induction process kept him out of the Army. Yet, it remains clear that the draft system afforded Springsteen, as well as young, working-class men like him, little agency in determining whether they would serve their country in the military.

Historian Christian Appy takes Baskir and Strauss's argument one step further. He argues that working-class men like Springsteen had far fewer options for avoiding the military in the

\footnotetext{
${ }^{5}$ Lawrence Baskir and William Strauss, Chance and Circumstance: The Draft, the War, and the Vietnam Generation (New York: Alfred A. Knopf, 1978).

${ }^{6}$ Dave Marsh, Bruce Springsteen: Two Hearts: The Definitive Biography, 1972-2003 (New York: Routledge, 2004), 232; Clinton Heylin, E Street Shuffle: The Glory Days of Bruce Springsteen \& the E Street Band (New York: Viking, 2013), 20-21.
}

BOSS: The Biannual Online-Journal of Springsteen Studies 2.1 (2016) 
Vietnam era than did middle-class men because of the way that the American government designed the system of military service. For instance, working-class men did not have the same access to recourses such as college deferment and doctors' letters, many of which were written by family friends to excuse healthy middleclass men from the military. Working-class men also had fewer social connections that might have led to an appointment in the Reserves or National Guard, which allowed eligible draftees to perform military service knowing that they were likely safe from being sent to the killing fields of Southeast Asia. ${ }^{7}$

On the cultural level, elements of working-class life predisposed young men from backgrounds such as Springsteen's to accept military life. Working-class men understood a military career as a normal and routine way of escaping the drudgery and poverty of a community in decline. To them, the military might even represent an escape valve from chronic unemployment in a place like Freehold, New Jersey, whose major factory, the A. \& M. Karagheusian rug mill, closed in the early 1960s. For middle-class men, by contrast, the Army threatened a career trajectory that promised a college degree, high-paying jobs, and professional success. Moreover, while middle-class men saw the military as a place of demeaning discipline and physically demanding work, working-class men often understood it as no less dangerous and no less taxing than the factory jobs performed by their fathers and brothers. ${ }^{8}$

\footnotetext{
7 Christian Appy, Working-Class War: American Combat Soldiers and Vietnam (Chapel Hill: University of North Carolina Press, 1993), 15, 42, 52.

${ }^{8}$ Appy, Working-Class War, 86-88.
}

BOSS: The Biannual Online-Journal of Springsteen Studies 2.1 (2016) 
Furthermore, working-class men often used the military in ways similar to the ways that middle-class men used college, as a way to get away from tense family situations like that between Bruce Springsteen and his father. Appy argues that for many working-class men, sadistic drill sergeants represented capricious authority figures. Yet, for those with cold and confrontational parents like Douglas Springsteen, military superiors imparted little real fear. By contrast, drill sergeants sometimes often showed more concern and compassion for their troops than many working-class fathers, themselves brutalized by a life of limited employment. ${ }^{9}$

The military offered an important cultural expression for working-class men in three ways. First, it provided them with an opportunity to express their masculinity. For instance, Douglas Springsteen saw the military's main value as making a "man" out of his disappointing, long-haired - and thus implicitly-feminineson. ${ }^{10}$ Second, the military provided economic and material security. For many men, service in the Armed Forces had little to do with political ideology and everything to do with the circumstances of communities that offered men few alternatives for economic survival. If nothing else, Appy argues, the military could provide food, housing, medical care, and-perhaps most importantly - get them thousands of miles away from home. ${ }^{11}$ The 1981 film Stripes successfully lampoons the disconnect between patriotism and military service. In a discussion in the barracks, one soldier humorously claims he joined the military because it offered

\footnotetext{
${ }_{9}^{9}$ Appy, Working-Class War, 70, 88.

${ }^{10}$ On the relationship between military service and the politics of Vietnam-era working-class manhood, see Robert Self, All in the Family: The Realignment of American Democracy Since the 1960s (New York: Hill and Wang, 2012), 47-74.

${ }^{11}$ Appy, Working-Class War, 49.
}

BOSS: The Biannual Online-Journal of Springsteen Studies 2.1 (2016) 
an inexpensive weight-loss program. Finally, avoiding military service in working-class communities carried with it a stigma of anti-patriotism that it no longer carried in most middle-class communities after the 1960s. The satirical humor of Stripes notwithstanding, white working-class men emerged as Vietnam War's most vocal home-front supporters. The so-called hard hat riot in Manhattan in 1970, which pitted pro-war construction workers against mostly middle-class protestors demanding an end to the war, revealed these tensions clearly and violently. ${ }^{12}$

These cultural associations could have accompanied Springsteen as he approached his impending Army physical in the late 1960s. Yet, despite his upbringing in financially precarious conditions and the threats from his father, Springsteen did not carry such positive associations with military life as did many of his working-class contemporaries. However much a young Bruce may have wanted to escape the confines of 1960s Freehold, he did not see the military as the way to do it. By 1982, moreover, he understood the ways that the system pressed working-class young men like himself into making choices that often led them into the military. The narrator of "Born in the U.S.A." joins the military because he finds himself in a "hometown jam," most likely due to a minor crime such as simple drug possession or petty theft. Like many young men who committed such crimes, the judicial system offers him the choice of the Army or jail, itself a damning commentary on the value and meaning the system ascribed to military service for working-class men. Springsteen's protagonist chooses the Army, putting his life at risk, but also wiping away the

12 On the 1970 "hard hat rally," see Jefferson Cowie, Stayin' Alive: The 1970s and the Last Days of the Working Class (New York: The New Press, 2012), 135-137, 347.

BOSS: The Biannual Online-Journal of Springsteen Studies 2.1 (2016) 
legal charges against him and offering him the chance to put his life back together should he survive the war and obtain an honorable discharge. Thus he goes "off to a foreign land / To go and kill the yellow man." At the end of the song, the narrator clings to his birthright despite finding himself "in the shadow of the penitentiary," an ironic fate for a character who served his country not out of a sense of patriotic duty, but in what Springsteen implies may be an ultimately failed attempt to avoid incarceration. ${ }^{13}$

The chance and circumstance that dictated working-class involvement in the Vietnam War era directly affected Springsteen's circle of friends and fellow musicians. Bart Haynes, the drummer in Springsteen's first band, The Castilles, joined the Marine Corps knowing that he would likely end up in Vietnam because he lacked the skills to find an assignment away from combat. Like many men of his generation, Haynes enlisted in the Marines to avoid the inevitable draft notice. ${ }^{14}$ Lacking means of avoiding conscription, Haynes and men like him could volunteer in order to, at the very least, control the timing of the military service they believed to be

${ }^{13}$ Cowie and Boehm, "Dead Man's Town," 373. Similarly, the protagonist of Ben Fountain's novel Billy Lynn's Long Halftime Walk-which examines the class politics of the twenty-first century military -joins the military to avoid going to jail for vandalizing his sister's fiancé's car; Ben Fountain, Billy Lynn's Long Halftime Walk (New York: HarperCollins, 2012).

14 Chance and Circumstance discusses the ways that men "volunteered" for services like the Air Force and the Navy in the hopes of avoiding being drafted into the Army. A popular Vietnam-era saying, "there ain't no Viet Cong submarines," captured the sentiment of what the military called "draftmotivated volunteers." For the same reason, thousands of middle-class men volunteered for ROTC training not because of any desire for a military career, but because ROTC came with a draft deferment. If a man stayed in school, he could avoid being sent to Vietnam for at least a few months or years. See Michael S. Neiberg, Making Citizen-Soldiers: ROTC and the Ideology of American Military Service (Cambridge: Harvard University Press, 2000).

BOSS: The Biannual Online-Journal of Springsteen Studies 2.1 (2016) 
unavoidable. Volunteering for the Armed Forces also struck some men as a more patriotic and honorable route than going into the military under coercion or using a disingenuous doctor's note to avoid military service. Politics played secondary roles in their decision making. As Springsteen notes in his monologue before "The River," Haynes could not even locate Vietnam on a map, let alone Quang Tri, where he died on October 22nd, 1967.15

Like many men from his generation, Haynes joined the military not because of any agreement with the goals of American foreign policy but because of a lack of other viable options. Perhaps with Haynes and other friends as inspiration, Springsteen wrote a number of songs about men who joined the Army out of economic necessity. The soldier who returns home in "Lost in the Flood" does not seem to exhibit any pride in his service, nor does Frank, the "no good" brother in "Highway Patrolman," for whom the military served as either a temporary respite from economic problems or, more probably, a burden to be borne when his number came due. Springsteen does not clarify whether military service had anything to do with Frank's violent nature, but he cleverly lets his listeners know that Frank served from 1965 to 1968, the years of escalation in Vietnam. Notably, the honorable and honest brother avoids military service using a farm deferment, one of the few options open to men from the rural heartland.

Thus, in Springsteen's pre-9/11 songs, the military is less a source of heroism and patriotism than a place where men go when other options fail them. This vision remains in line with the classdetermined opportunities inherent in modern military service. Sociologists Charles Moskos and Martin Binkin have described

15 Peter Ames Carlin, Bruce (New York: Touchstone, 2012), 35.

BOSS: The Biannual Online-Journal of Springsteen Studies 2.1 (2016) 
military service as a tradeoff of what Binkin deems "benefits versus burdens." 16 The benefits include technical training of use to civilian employers, a chance to acquire a college education at government expense, and the possibility of a long military career with lifetime benefits. The burdens most obviously include risking one's life, but they also include time away from the civilian job market while one's peers begin their careers. Thus, while a twenty-year military career might place a working-class man or woman ahead of his or her peers economically, a brief stint might, by contrast, place that person at an economic disadvantage relative to those same peers. Contrary to the recruiter's pitch, three years spent as a draftee normally reinforced the economic patterns that kept men intermittently employed or, at least, employed below the level of their peers. ${ }^{17}$

Springsteen's soldiers suffer burdens of military service much more than they enjoy its benefits. None of the characters in Springsteen's songs makes the military a career or describes it as a haven from the cyclical unemployment of post-industrial America. Furthermore, Springsteen's working-class characters find even their limited benefits inaccessible. The protagonist of "Born in the U.S.A.," for instance, is unable to claim benefits from his Veterans Affairs representative. Springsteen's other military characters serve in some of the Army's worst jobs. Lieutenant Jimmy Bly from

\footnotetext{
${ }^{16}$ Martin Binkin and Mark J. Eitelberg with Alvin J. Schexnider and Marvin M. Smith, Blacks and the Military, (Washington D.C.: The Brookings Institution, 1982), 62.

17 See Martin Binkin and John Johnson, All-Volunteer Armed Forces: Progress, Problems, and Prospects (Washington, D.C.: Brookings Institute, 1973) and Charles Moskos and Frank R. Wood, The Military: More Than Just a Job? (Dulles, VA.: Brassey's, 1988).
}

BOSS: The Biannual Online-Journal of Springsteen Studies 2.1 (2016) 
1992's "Souls of the Departed" is a rare officer in Springsteen's catalogue, but he has the awful task of going through the belongings of soldiers killed on their way to Basra in the First Gulf War. While he has trained to be a platoon leader, Lieutenant Bly's unit is no band of brothers. Rather, his comrades have become smoky wraiths rising "like dark geese into the Oklahoma skies." His low-skill and low-prestige job will provide few marketable or transferable skills in demand by civilian employers after he leaves the Army. Indeed, most of Lieutenant Bly's family and friends will not want to hear about his service, and one suspects that Bly himself will keep it bottled inside for the rest of his life.

Springsteen's military characters are not cowards. Nor are they naturally violent people, Frank from "Highway Patrolman" notwithstanding. Like the downtrodden steel workers in Michael Cimino's film The Deer Hunter (1978), Springsteen's soldiers have merely moved from one desperate situation to another. Military service to them is simply another rite of passage, much like marriage or entry into the dangerous world of the steel mills. Frank would have fit in well with the characters in Cimino's film, brutalized as they all are by their wartime service. He also would have fit well, however, with characters from the genre of films showing Vietnam veterans as unstable, violent, and desperate, for instance Sonny Wortzik in Dog Day Afternoon (1978) and Travis Bickle in Taxi Driver (1976).

Springsteen's music between the release of Greetings from Asbury Park, N.J. (1972) and Magic (2007) evidences far less overt war-related themes than does the music of contemporaries like Bob Dylan, Jackson Browne, Neil Young, and John Fogerty. Yet, when Springsteen does address military matters, he peers through a 
particular class-oriented lens. Most prominently, in 1995's "Youngstown," Springsteen speaks on behalf of an industrial community in the wake of deindustrialization: "we gave our sons to Korea and Vietnam / Now we're wondering what they were dying for." Springsteen's narrator angrily decries the waste and senselessness of these wars. Yet, the song is not a political tirade against interventionist American foreign policy. Rather, the narrator focuses his anger on the injuries suffered by the American working-class. In previous decades, the workers of Youngstown "built the tanks and bombs that won this country's wars," yet the city's factories-which provided the site of both gainful employment and national service-have been taken away from them. Springsteen draws a parallel between the abandonment of the town and the abandonment of the veterans of the Korean and Vietnam wars, aiming his critique at the way these conflicts turned working-class men into angry, bitter, and forgotten veterans.

The themes of individual suffering for mistakes of American foreign policy emerge most clearly on "The Wall," a song released on High Hopes (2014) that Springsteen co-wrote with Joe Grushecky after a visit to the Vietnam War Memorial in 1997. Springsteen played the song four times before its release, twice at benefit concerts and, tellingly, twice on the Devils $\mathcal{E}$ Dust (2005) tour at the height of the Iraq War. During one of those live performances, Springsteen told the audience that he wrote the song for a friend who joined the Marine Corps and was killed in Vietnam. ${ }^{18}$ On the High Hopes tour, an acoustic version preceded a fully-electric "Born

18 Stan Goldstein, "Are These the 12 Songs on a New Bruce Springsteen Album?," November 23, 2013, accessed July 18, 2016:

http://www.nj.com/springsteen/index.ssf/2013/11/are_these_the_12_songs_ are_a_n.html.

BOSS: The Biannual Online-Journal of Springsteen Studies 2.1 (2016) 
in the U.S.A.," underscoring the enduring importance of military themes to Springsteen's canon, both old and new.

"The Wall" begins with the narrator recalling an unnamed soldier in his Marine Corps uniform nervously laughing and joking about his upcoming deployment to Vietnam. The song is delivered as a monologue directed at this figure, who is clearly deceased and was therefore most likely inspired by Haynes. The narrator's anger is tinged with class-consciousness, particularly against "the men who put you here" who "eat with their families in rich dining halls." Unusually for Springsteen, this song names individual political actors, ending the first stanza with the line "I read Robert McNamara say he's sorry," a reference to the Vietnam-era Secretary of Defense's apologia published in 1996, the year before Springsteen's visit to the memorial. ${ }^{19}$ "The Wall" presents an angry treatment of the sacrifices of a generation and the suffering loved ones left behind. It also provides a scathing indictment of a system that allowed some to get rich from military contracts while working-class men reluctantly risked their lives for unclear causes in far-away places. As the narrator of "The Wall" watches limousines ride down Pennsylvania Avenue, he takes aim at McNamara with the final line, "apology and forgiveness have no place here at all."

The narrator of "The Wall" is not the only Springsteen character who copes with class-tinged anger following death of a loved one in combat. "Gypsy Biker," from Magic, captures the

\footnotetext{
${ }^{19}$ Robert S. McNamara, In Retrospect: The Tragedy and Lessons of Vietnam (New York: Vintage, 1996). McNamara claims in the book that he knew early on that America would likely fail in Vietnam but he did too little to stop the war's escalation. See also Brian VanDeMark, Into the Quagmire: Lyndon Johnson and the Escalation of the Vietnam War (New York: Oxford University Press, 1991).
}

BOSS: The Biannual Online-Journal of Springsteen Studies 2.1 (2016) 
anger of a community following the death halfway around the world of an enlisted loved-one. The song illustrates that the system has not just failed the men coming home from the war, but has also exploited them while profiteers and speculators have grown rich off the same war where soldiers shed their blood. Seeking relief from their grief, the dead man's friends and family turn to alcohol, drugs, and eventually a ritualistic burning of the dead man's prized motorcycle.

Like the community members of "Gypsy Biker" and the narrator of "The Wall," Springsteen also experienced the events of the Vietnam War from a comfortable-if-disorienting distance. As his class-consciousness emerged more fully on Darkness on the Edge of Town (1978), he began to understand in broader, political terms what the war had done to the men of his generation who had fought it. Springsteen read Ron Kovic's Born on the Fourth of July (1976) and, by a remarkable coincidence, met Kovic at a southwestern roadside motel shortly thereafter. After getting to know Kovic and becoming more interested in the cause of Vietnam veterans, Springsteen dedicated a song to Kovic during two shows in San Francisco in 1978. As in his choice of "The River" a few years later, however, the song he dedicated to Kovic had nothing directly to do with war. Springsteen performed "Darkness on the Edge of Town," a song normally introduced with a story about his father. By mentioning Kovic and his book instead in his introduction, Springsteen connected a song replete with class-laden despair to Kovic's story of an abandoned Vietnam veteran. Springsteen's performance thus suggested that Douglas Springsteen and Ron Kovic were both men trapped by their circumstances beyond their control. Douglas may have let his failures drag him down, but 
Kovic cut loose from his demons and bravely fought against the darkness he saw around him after he returned from Vietnam.

In a 1998 interview, Springsteen tied Kovic's writing to that of American Gothic writers Flannery O'Connor and Walker Percy, who could reach "the heart of some part of meanness" in the American experience. ${ }^{20}$ Springsteen saw the impact of the military and war-as well as the nation's willingness to toss aside its veterans - as central parts of that meanness. Instead of providing an indictment of war itself, Springsteen's songs that deal with the military protest the way the burdens of these wars are borne disproportionately by the working-class. The immorality of war appears as a theme far less often in the Springsteen discography than the meanness with which American society has treated the men it has sent to fight wars it later repudiated. Just as American industry used blue collar men before tossing them aside once they were no longer needed, so, too, did the government toss aside working-class soldiers once the war that required their sacrifice had ended. Both themes appear intertwined in songs like "Highway Patrolman," "Born in the U.S.A.," and "Youngstown." In these songs, the military is viewed as just another greedy industry, robbing working-class men of their youthful idealism and then throwing them away once they are no longer needed.

To Springsteen, the lack of recognition of the struggle of Vietnam veterans reveals American "meanness" at its worst. In a telling statement, Springsteen noted at a 1981 benefit concert for Vietnam Veterans of America that the treatment of Vietnam veterans like Kovic was analogous to "walking down a dark street

${ }^{20}$ Interview with Will Percy in Jeff Burger, ed. Springsteen on Springsteen:
Interviews, Speeches, and Encounters (Chicago: Chicago Review Press, 2013), 247.

BOSS: The Biannual Online-Journal of Springsteen Studies 2.1 (2016) 
at night, and out of the corner of your eye you see somebody getting hurt ... but you keep walking on." 21 The injuries of Vietnam had not struck Springsteen directly, but he easily linked the experiences of veterans with those of the working-class men and women who so deeply informed his own vision of America and its limitations.

Thus, like many Americans in the 1980s, Springsteen was able to disassociate Vietnam veterans from the highly divisive war they fought and from the damaging stereotypes of them that had been prevalent in the 1970s. He had come to see Vietnam veterans not as perpetrators of a mistaken conflict or psychologically broken symbols of a national humiliation but as working-class victims of a war they had not wanted to get involved with in the first place. In doing so, he followed a general American trend that restored the Vietnam veteran from the symbol of a failed war and converted him - it was invariably a "him" - into one of its central victims. In contrast to cultural depictions of veterans in the 1970s, 1980's television shows like Magnum PI (1980-1988) presented welladjusted and successful Vietnam veterans who had managed to put the war behind them. Even those veterans badly damaged psychologically by the war, like Frank from "Highway Patrolman," became sympathetic figures because of their suffering. Thus, most viewers cheered for intensely violent characters like Sylvester Stallone's John Rambo from First Blood (1982) and Mel Gibson's Martin Riggs from Lethal Weapon (1987). These characters appear not as sociopaths-like Travis Bickle does in Taxi Driver-but as products of a distant war. Their violent tendencies do not prove

${ }^{21}$ Quoted in Marc Dolan, Bruce Springsteen and the Promise of Rock ' $n$ ' Roll (New York: Norton, 2013), 186.

BOSS: The Biannual Online-Journal of Springsteen Studies 2.1 (2016) 
intrinsic to them-or, by extension to the American people more generally - but instead present the consequences of the terrible war in which they fought against their will but also to the best of their abilities. $^{22}$

While much of Springsteen's music turned introspective and personal in the late 1980s and 1990s, the tragic events of September 11 th, 2001 brought war and the military back to the forefront of American consciousness. Springsteen, whose New Jersey community was directly impacted by the terrorism of that day, produced The Rising (2002), one of the most powerful cultural products in response to the events of 9/11. The focus of that album, however, has little to do with soldiers. Instead it re-contextualizes existing songs like "My City of Ruins" to meet the needs of the day and focuses on the working-class first responders like the men in the title track, "Nothing Man," and "Into the Fire." Brendan O'Brien, who produced the album, noted that they did not work with an explicit 9/11 theme in mind, although one emerged organically from the songs eventually featured on the album. ${ }^{23}$

Like most Americans, Springsteen supported military action in Afghanistan to remove the threat posed by Al Qaeda and the Taliban, going so far as to place a note on his web site in favor of the war in Afghanistan. Yet, as the Rising tour went on, Springsteen began to play "Born in the U.S.A." more often, an admonition that

\footnotetext{
22 Think also of the characters in the TV drama "The A-Team" (1983), who met one another during the Vietnam War but had to go into hiding after being framed for a crime "they did not commit" by a corrupt government. As is the case with First Blood, the audience blames the government, not the soldiers.

${ }^{23}$ Carlin, Bruce, 415.
}

BOSS: The Biannual Online-Journal of Springsteen Studies 2.1 (2016) 
the country could not risk abandoning its Afghanistan veterans as it had once abandoned its Vietnam veterans. ${ }^{24}$

Springsteen's political activism and concerns over interventionism emerged more fully following the passage of the Patriot Act and the George W. Bush Administration's decision to invade Iraq in 2003. Springsteen's shows began to feature longer and more politically-charged monologues and his cover of Edwin Starr's "War" appeared on set lists more often, a far more explicit statement about Springsteen's views on the folly of the war in Iraq. The Iraq War also brought Springsteen front and center into the realm of partisan politics when he began to campaign first for Democratic presidential candidate John Kerry in 2004 and then for Barack Obama in 2008. As Springsteen told an interviewer, "sitting on the sidelines would be a betrayal of the ideas I'd written about for a long time." Perhaps with Vietnam in mind, he noted, "Not getting involved, just sort of maintaining my silence ... wasn't going to work out this time." 25

Springsteen's turn to direct political activism-and the consequences of the new American foreign interventionism on the working-class-was strongly reflected in his next two studio albums, Devils $\mathcal{E}$ Dust (2005) and Magic (2007). The title track of the former returned Springsteen to one of those ideas he had written about for decades: the impact of war on the individual soldier. In the song's opening line, a soldier narrator states that he has his finger resting on the trigger of his assault rifle. Though listeners are not told where the soldier is located the narrator appears prepared to defend the ideals for which the United States invaded Iraq in

\footnotetext{
${ }^{24}$ Dolan, Bruce Springsteen, 376.

${ }^{25}$ Carlin, Bruce, 418.
}

BOSS: The Biannual Online-Journal of Springsteen Studies 2.1 (2016) 
2003. Yet, like Springsteen himself, the soldier doubts those ideals and wonders if they are instead built on a deadly façade of misguided religion and blind patriotism. Unlike Springsteen, however, the character in the song lacks the freedom to publicly protest the war. Instead, he turns to his comrades for redemption, a tactic also taken by Springsteen's characters in songs such as "Gypsy Biker" and "Brothers Under the Bridge." Although "Devils and Dust" is the most avowedly political song on the album, it does not directly target the Bush administration or mention the word "Iraq." Instead, the song presents the kind of moral dilemma that tormented the narrator of "Highway Patrolman." Despite his doubts, the narrator of "Devils \& Dust" sees little choice but to bury his uncertainties and fight on, less for the goals of the administration he serves than for his comrades. He knows the war will blacken his heart and he may even suspect that his fellow Americans will reject him once he returns home, but he also sees few other options.

Springsteen's We Shall Overcome: The Seeger Sessions (2006) invokes the past to speak to the present by including the Irish folk protest song "Mrs. McGrath." Originally written in 1811 in protest of British attempts to recruit Irish soldiers for Britain's wars against Napoleon, the song fits with Springsteen's vision of the interactions of class and military service. In Springsteen's version, a recruiting sergeant has convinced a widow to let her son join the army, though she has no idea what the war is about or how it will affects her. Her son, Ted, returns seven years later having lost both of his legs to a cannonball. In Springsteen's version, the mother cries that foreign wars live on the blood of soldiers and the pain of their

BOSS: The Biannual Online-Journal of Springsteen Studies 2.1 (2016) 
mothers, a sentiment the characters of "Gypsy Biker" understand as well.

The songs on Magic followed some of these themes, depicting a nation and another generation of soldiers deceived into a war by a web of lies. In particular, Springsteen draws implicit connections between Iraq and Vietnam, especially in "Last to Die." Released at the height of domestic turmoil over the Iraq War, the song's title was inspired by John Kerry's 1971 testimony before Congress's Fulbright Committee. Kerry, a Vietnam veteran, advocated for immediate withdrawal from Southeast Asia as a representative of Vietnam Veterans Against the War, asking: "How do you ask a man to be the last man to die in Vietnam? How do you ask a man to be the last man to die for a mistake?" 26 More than three decades later, after Kerry had risen to become a United States senator and presidential candidate, Springsteen revived the line as well as the sentiment of Kerry's testimony. In "Last to Die," Springsteen deftly transitions from a verse about a military convoy riding toward a burning Iraqi city to an average American family driving with their children asleep in the car's backseat. The civilians no longer consider the distance between themselves and the soldiers they have sent off to war, a damning indication that they will also be willing to forget the men and women of that war once they return home, a common criticism of the relationship of

\footnotetext{
${ }^{26}$ Democracy Now! " “John Kerry Then: Hear Kerry's Historic 1971 Testimony Against the Vietnam War," February 20, 2004:

http://www.democracynow.org/2004/2/20/john_kerry_then_hear_kerrys_hi $\underline{\text { storic }}$
}

BOSS: The Biannual Online-Journal of Springsteen Studies 2.1 (2016) 
the military and society since the shift from a draft-based system to an All-Volunteer Force (AVF) in 1973. ${ }^{27}$

Springsteen released Magic in August 2007, just six months after the scathing Washington Post exposé on shoddy care for veterans at Walter Reed Army Medical Center vaulted the issue of veterans' services onto front pages, televisions, and internet sites across the country. ${ }^{28}$ As the scandals in the military health care system began to multiply, Springsteen saw echoes of the way that the Vietnam era system had failed a previous generation of veterans. Thus, Springsteen performed at the 2012 and 2013 Stand Up for Heroes benefit concerts for wounded warriors despite-or perhaps precisely because of -his opposition to the war in Iraq. ${ }^{29}$ For Springsteen and for most of the performers, the benefit, which aids the Bob Woodruff Foundation, is less a statement of opposition to a misguided foreign policy decision than a statement about the need to help veterans who fought that war and now face the same lack of support from their own society faced by the soldier in "Born in the U.S.A." To Springsteen, there is no contradiction in opposing a war but helping the men and women who fought it, especially those victimized both by the war and the failures of the American system. Thirty years later, with the Americans wars in Iraq and Afghanistan burned out but constantly threatening to reignite, with

${ }^{27}$ On the transition to the AVF, see Beth Bailey, America's Army: Making the AllVolunteer Force (Cambridge: The Belknap Press of Harvard University Press, 2009).

${ }^{28}$ Dana Priest and Anne Hull, "Soldiers Face Neglect, Frustration At Army's Top Medical Facility," Washington Post, February 18, 2007.

${ }^{29}$ Tris McCall, "Bruce Springsteen to sing at Stand Up For Heroes," September 9, 2013, accessed July 18, 2016

http://www.nj.com/entertainment/music/index.ssf/2013/09/bruce_springst een_to_sing_at_stand_up_for_heroes.html

BOSS: The Biannual Online-Journal of Springsteen Studies 2.1 (2016) 
the Veterans Administration hospital system still in disarray, and with military suicides occurring with sickening frequency, the problem tragically remains, as does the need to speak - and sing about it.

BOSS: The Biannual Online-Journal of Springsteen Studies 2.1 (2016) 